
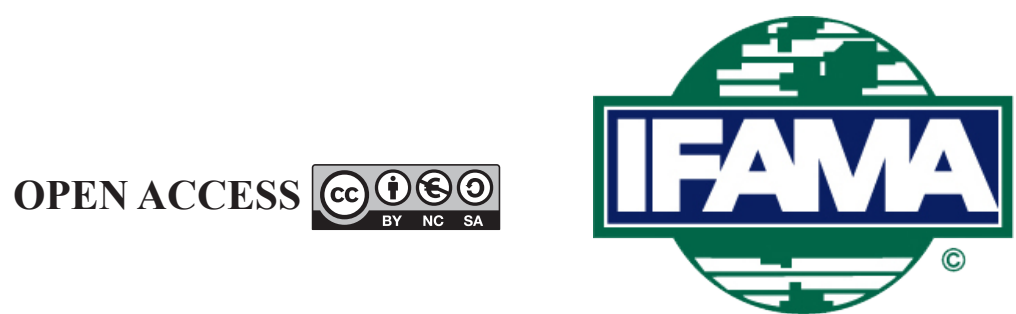

International Food and Agribusiness Management Review

Volume 24, Issue 4, 2021; DOI: 10.22434/IFAMR2020.0210

Received: 16 December 2020 / Accepted: 26 March 2021

Special Issue: Growth of agroholdings and mega-farms in transition and emerging market economies: institutional and organizational aspects

\title{
Broadening the scope of instrumental motivations for CSR disclosure: an illustration for agroholdings in transition economies RESEARCH ARTICLE
}

Taras Gagalyuk $^{\circledR a}$, Lioudmila Chatalova ${ }^{\mathrm{a}}$, Oleksandr Kalyuzhnyy ${ }^{\mathrm{b}}$ and Igor Ostapchuk ${ }^{\mathrm{c}}$

${ }^{a}$ Senior Researcher, ${ }^{c}$ Research Associate, Department of Structural Development of

Farms and Rural Areas, Leibniz Institute of Agricultural Development in Transition Economies (IAMO), Theodor-Lieser-Strasse 2, 06120 Halle (Saale), Germany

bAnalyst, Association 'Ukrainian Agribusiness Club' (UCAB), Maidan Nezalezhnosti 2, 01012 Kyiv, Ukraine

\begin{abstract}
Large firms operating in underdeveloped institutional environments of transition economies tend to invest in seemingly unrewarded corporate social responsibility (CSR) initiatives. To explain this phenomenon, we extend the literature on the motives behind CSR disclosure in agribusiness from the institutional perspective on organizational legitimacy. The thesis is that self-interest rationales for CSR disclosure, as advocated by the strategic-legitimacy perspective, fall short of explaining the full scope of instrumental motivations for the proactive and excessive transparency initiatives of agribusiness companies. Using the example of internationally listed Ukrainian agroholdings, we show that firms faced with institutions that do not appropriately support access to market transactions not only adapt to fluctuations in the business environment but also proactively address key institutional bottlenecks by engaging in higher transparency and nonmarket initiatives. The case study analysis of the voluntary CSR disclosure of four agroholdings is conducted based on in-depth interviews with corporate managers and complemented with information from corporate reports and websites. This analysis offers insights into the development of corporate farming and its economic and social repercussions in Ukraine and, more generally, expanding the concept of CSR itself.
\end{abstract}

Keywords: agroholdings, corporate social responsibility disclosure, institutional legitimacy, strategic legitimacy, transition economy

JEL code: Q13, M14, D23, D63, O16, P31

\footnotetext{
${ }^{\circledR}$ Corresponding author: gagalyuk@iamo.de
} 


\section{Introduction}

Firms' corporate social responsibility (CSR) reporting has steadily gained scholarly attention over the last decades (Thorne et al., 2014). CSR is generally defined as actions that appear to further a social good beyond the interests of the firm and that is required by law (cf. McWilliams and Siegel, 2001: 117). Thus, firms reporting on CSR to their stakeholders aim to simplify access to their activities on environmental and social issues (Thorne et al., 2014). Numerous recent inquiries into this area are framed largely by attempts to reveal instrumental motivations behind firms' CSR disclosure and communication. Research focuses on economic or financial returns from engaging in initiatives that go at least partially beyond the firm's core business operations (Carroll and Shabana, 2010; Vogel, 2005). Accordingly, the instrumental rationale for CSR disclosure builds on the assumption that there is a positive relationship between higher disclosure quality and a firm's self-interest in the form of any tangible benefits (Dhaliwal et al., 2014; Verrecchia, 2001).

This view of corporate transparency has been widely addressed through the lens of strategic organizational legitimacy (Suchman, 1995). Generally, the strategic approach to organizational legitimacy adopts a managerial perspective and emphasizes the ways in which organizations instrumentally manipulate and deploy evocative symbols to gain social support (ibid.: 572). Within the strategic approach to organizational legitimacy, firms' CSR disclosure has been an object of research scrutiny from economic, resource-based and stakeholder perspectives. The economic (e.g. agency cost) literature has discussed the benefits of CSR disclosure in relation to a firm's ability to systematically fulfill the information needs of investors and increase shareholder value (Raithel and Schwaiger, 2015). Another important line of inquiry relates to the benefits that accrue from disclosure to the general public, framed primarily by resource-based traditions (Raithel and Schwaiger, 2015; Rindova et al., 2010). The stakeholder perspective extends this view by suggesting that a firm discloses information to meet the demands and expectations of a broad range of stakeholders (Thorne et al., 2014). In general, the focus on stakeholders' awareness of the appropriateness of a firm's behavior and respective effects on shareholder value appears to dominate these research domains (Beiting et al., 2014; Bennis et al., 2008; Rindova et al., 2010). However, none of these perspectives explain firms' involvement in CSR disclosure amid low societal demands and expectations for a transparent action.

The agricultural sector of transition economies serves as a particularly strong platform for more in-depth scrutiny of a broader scope of motivations for CSR disclosure. The sectors of primary agriculture in countries such as Kazakhstan, Russia and Ukraine are marked by a rapid development of so-called agroholdings (Hermans et al., 2017). An agroholding generally stands for a corporate entity consisting of a mother company that has control over dozens or hundreds of farms and operates dozens or even hundreds of thousands of hectares of farmland (ibid.: 177). Particularly in view of limited access to finance on domestic markets, agroholdings from transition countries are impelled to attract capital from the equity markets of developed economies (Hermans et al., 2017; Petrick et al., 2013). On the one hand, this activity requires agroholdings to increasingly disclose their financial ownership and, since recently, CSR information in accordance with the requirements of international stock markets (UCAB, 2012). On the other hand, the scope of CSR information voluntarily disclosed by agroholdings often tends to be broader than that required by markets and society and includes reporting on agroholdings' community development initiatives, employee relations, infrastructural projects and environmental performance (Gagalyuk, 2017).

At the same time, existing institutional settings for corporate transparency in transition countries, such as corporate governance laws and regulations or independent audits, are neither strong enough nor led by the public interest (Langbein, 2015; Love and Rachinsky, 2015; Mycyk et al., 2007). Furthermore, local public perceptions of agroholdings in transition economies are not necessarily negative (Mamonova, 2015; Stepanenko, 2006). Moreover, unlike Western-type CSR reporting (Jauernig and Valentinov, 2020; Visser et al., 2019), the CSR disclosure of agroholdings, e.g. in Ukraine, is seemingly more often characterized by a match between CSR action and CSR communication. Ukrainian agroholdings have been shown to engage in a broad set of CSR initiatives ranging from ad hoc support of individual rural inhabitants to investments in 
technical infrastructure in rural communities, e.g. the construction of roads and electricity lines and charitable donations to rural schools, churches and sport clubs (Gagalyuk et al., 2018).

On reflection, these developments call for an extension of the existing, but still very limited, CSR disclosure studies in the agribusiness research. In particular, the strategic legitimacy-centered view of higher CSR disclosure driven by international listings (Gagalyuk, 2017) and by the stakeholder perspective (Gagalyuk et al., 2018; Jauernig and Valentinov, 2019) should be extended by the notion that corporate disclosure may pursue certain higher-order objectives. Given the existing market imperfections and highly nontransparent business environments of transition economies (Durnev et al., 2009; Keyzer et al., 2013), one such objective may be the establishment of functioning market-based institutions that generate benefits for firms. If this argument is correct, then the instrumental rationale behind CSR disclosure (at least in transition countries) should be broader. The present paper aims to incorporate this view. In particular, we argue that the instrumental self-interest rationale for CSR disclosure advocated by the strategic legitimacy perspective should be complemented by the institutional perspective on organizational legitimacy. We suggest that the latter enables us to consider and explain a broader set of firm benefits from transparent business practices adopted in poor institutional environments.

Using the example of publicly listed Ukrainian agroholdings, the paper scrutinizes antecedents (and outcomes) of firms' CSR disclosure in transition economies. Recent developments in Ukrainian agribusiness, with 21 (of approximately 100) very large agroholdings listed on international stock markets, appear particularly instructive. These large producers have gained systemic importance and generated significant policy-shaping power (Luyt et al., 2013; Mamonova, 2015; Miranda and Grandori, 2020). Studying the relationships between their corporate transparency policies, corporate growth indicators and concomitant changes in institutional structures promises insights into the development trajectories of corporate farming and its economic and social repercussions.

We develop our argument in three steps. We begin with an overview of the literature on firms' motivations to engage in CSR communication to deliver a theoretical framework for the extended instrumental perspective on voluntary CSR disclosure. Then, we outline the institutional environment of Ukrainian agroholdings. Finally, the application of the proposed framework is illustrated through case studies of selected publicly listed agroholdings.

\section{Firms' motivations for CSR disclosure: the strategic and institutional perspectives on organizational legitimacy}

Corporate transparency serves as an important source of organizational legitimacy ${ }^{1}$ in a social system (Thorne et al., 2014) and as such is of strategic instrumental interest from a managerial standpoint (Bennis et al., 2008; Schnackenberg and Tomlinson, 2016). Corporate transparency's strong signaling effects for creditors and investors and self-disciplinary effects on management have been widely acknowledged as essential to corporate viability (Dhaliwal et al., 2011; Fung, 2014; OECD, 2004). The literature largely deals with transparency by scrutinizing specific leading interests in communicating corporate activities, such as trust building (Perotti and Von Thadden, 2005), impacts on dominant investors (Pirson and Malhotra, 2011) or the creation of a candid corporate culture (Serpa, 1985). Meanwhile, corporate transparency is taking on a new meaning of more extensive and proactive disclosure, which goes beyond mandatory corporate details (Bujaki and McConomy, 2002; Li, 2010).

The present paper revisits this debate by diverting attention to a broader scope of instrumental rationales for corporate transparency. In particular, we focus on CSR disclosure as an important instrument for gaining and maintaining legitimacy. We argue that the strategic view of organizational legitimacy and, accordingly,

\footnotetext{
${ }^{1}$ Here, we refer to legitimacy as a generalized perception or assumption that the actions of an entity are desirable, proper, or appropriate within some socially constructed system of norms, values, beliefs, and definitions (Suchman, 1995: 574).
} 
of CSR disclosure should be complemented by the institutional perspective on legitimacy. The distinction between strategic and institutional approaches to organizational legitimacy is not novel (Elsbach, 1994; Oliver, 1991; Suchman, 1995). However, surprisingly enough, this distinction has rarely been addressed in studies on CSR (disclosure) in agribusiness. Instead, the research on CSR and CSR disclosure in agribusiness is dominated by the strategic legitimacy perspective (Gagalyuk, 2017; Luhmann and Theuvsen, 2016). The present paper partly addresses this gap by employing the institutional approach to CSR disclosure alongside the strategic approach.

\subsection{CSR disclosure from the strategic legitimacy perspective}

Research on strategic legitimacy depicts legitimacy as an operational resource that organizations extract often competitively - from their cultural environments and that they employ in pursuit of their goals (cf. Suchman, 1995). As such, this approach assumes that there is a recurrent conflict between an organization's managers and stakeholders over the form of legitimation activities. On the one hand, there are managers who favor flexible and efficient activities. On the other hand, stakeholders prefer more substantive responses (Pfeffer and Salancik, 1978; Suchman, 1995). Accordingly, from this perspective, CSR disclosure presents an efficient means for a firm to attain tangible benefits in the form of shareholder value and to manage its external image to capture value from the market.

\section{- Economic motives for CSR disclosure}

Until recently, research has found little or no evidence of shareholders' interest in firms' CSR disclosure. This development has largely been explained by the short-term profit orientations of investors and shareholders. Pressures to show short-term returns predispose owners to support investment in socially responsible initiatives only when there is an immediate positive effect on profits (cf. Aguilera et al., 2007: 845). However, more recent studies on CSR reporting find a positive association between levels of firms' CSR disclosure and share prices (Ioannou and Serafeim, 2015), especially in industries highly sensitive to environmental concerns (De Klerk et al., 2015) or consumer perceptions (Lev et al., 2010). To this end, investment analysts tend to increasingly assess these firms more optimistically over time. In investment analysts' assessments, such positive relationships are predicated on the condition that both internal and external CSR activities are addressed (Beiting et al., 2014; Hawn and Ioannou, 2016). As a result, nonfinancial disclosure or integrated reporting is becoming increasingly important (Rupley et al., 2017), while some jurisdictions, e.g. the EU, are even adopting legislation ${ }^{2}$ that explicitly requires firms to report on their social, environmental and human rights impacts (Kinderman, 2019).

\section{- Resource-based motives for CSR disclosure}

Broadening the analytical focus from a shareholder to stakeholder perspective enables a new and more comprehensive understanding of the CSR disclosure concept that goes beyond the agency cost argument and adopts a resource-based rationale for CSR disclosure (Jahansoozi, 2006; Rawlins, 2009; Yang and Rivers, 2009). Within this research stream, the extent of disclosed information has been shown to positively influence corporate image (Plotnick, 2010) and the mutual recognition and resolution of normative conflicts (Palazzo and Scherer, 2006; Scherer and Palazzo, 2007). In turn, the general public's perceptions of a firm's reputation and responses to societal expectations have been shown to noticeably (although in part indirectly) affect future shareholder value (Galuchi et al., 2019; Raithel and Schwaiger, 2015; Rindova et al., 2010; Roberts and Dowling, 2002). With consumers, employees and investors being increasingly interested in the social and environmental performance of companies, corporate reputation represents a unique and valuable resource. Therefore, CSR disclosure gains importance as an instrument of corporate communication, collective identity and social legitimation (Gider and Hamm, 2019; Schnackenberg and Tominlson, 2016; Widmar et al., 2019).

\footnotetext{
${ }^{2}$ Directive 2014/95/EU, also called the nonfinancial reporting directive (NFRD), establishes rules on the disclosure of nonfinancial and diversity information by large companies. The directive amends accounting directive 2013/34/EU. Companies are required to include nonfinancial statements in their annual reports from 2018 onwards (cf. EU, 2014).
} 
In this respect, a firm's transparent assumption of responsibility for, for example, the natural environment, employees and supply chain partners may bring about a range of tangible benefits (Hellberg-Bahr and Spiller, 2012; Hoogiemstra, 2000; Widmar et al., 2019). For instance, firms able to properly address changing stakeholder needs may enjoy improved access to bank loans, sales growth and higher operating margins (Beiting et al., 2014; Bennis et al., 2008). This capacity not only drives shareholder value (Raithel and Schwaiger, 2015) but also provides firms with competitive advantages (Ioannou and Serafeim, 2015; Jauernig and Valentinov, 2019) and supports sustainable growth (Zink, 2005). Moreover, this relationship is reciprocal, as corporate reputation has a positive effect on accounting performance, namely, by motivating firms to be transparent and to disclose information about themselves more intensively (Roberts and Dowling, 2002).

\subsection{CSR disclosure from the institutional legitimacy perspective}

From the strategic perspective, corporate transparency policies may be often viewed as symbolic responses to external criticism (Shell, 2004) or tactical actions aimed at responding to the information needs of the most salient constituents, e.g. consumers or shareholders (Ashforth and Gibbs, 1990; Janning et al., 2020a). By contrast, the institutional perspective depicts legitimacy not as an operational resource but as a set of constitutive beliefs (Suchman, 1995). Accordingly, organizations do not simply extract legitimacy from the environment. Rather, external institutions, either strong or weak, affect the organization in every respect and determine how it is established, run and perceived. Within this tradition, legitimacy and institutionalization are virtually synonymous, while the institutional perspective downplays both managerial agency and manager-stakeholder conflict. The instrumental reward is mainly viewed as a peripheral component of the larger cultural construct (ibid.: 576).

However, the institutional approach to legitimacy does not imply a full absence of instrumental motivations for an organization's legitimation activities. When viewed from this perspective, a firm engages in CSR disclosure not only because of some direct economic interests but also due to higher-order motives (Davis et al., 1997) or a necessity to address weaknesses in the institutional environment (Brousseau and Raynaud, 2011). Given ongoing processes of globalization and the involvement of firms in operations in different economic contexts, the institutional frameworks for corporate activities, including disclosure, may substantially differ or be underdeveloped, incomplete or even missing (Scherer and Palazzo, 2007). These institutional constraints faced by firms are susceptible to modification through deliberate strategic action (cf. Dorobantu et al., 2017: 116).

Particularly in the business environments of developing and transition economies, firms may be exposed to simultaneous and significant effects of nontransparent practices persisting in the spheres of property rights protection (Love and Rachinsky, 2015), ecological sustainability (Bansal and Roth, 2000), human resource management (Ledeneva, 2008) or access to land (Visser et al., 2012). In such turbulent environments, organizational resilience rather than economic efficiency comes to the forefront as an instrumental motivation for firms' broader socialization (Gagalyuk and Valentinov, 2019). Furthermore, Balmann et al. (2016) propose that the normative motivation for firms to engage in positive social change may transform into instrumental motivation due to the complexities or weaknesses of the institutional environment. Thus, if a firm's CSR disclosure is able to improve the larger institutional (or cultural) environment, the resulting instrumental reward is no longer peripheral for the firm.

In the context of agroholdings, several studies show that these large farming entities increasingly voluntarily disclose more CSR-related information rather than when required by law or consumers' and shareholders' expectations. For instance, Visser et al. (2019) find a rather negative tendency toward CSR overreporting and neglect of important stakeholders' interests in the Krasnodar Krai of Russia. The authors relate this finding to the Anglophone-type symbolic response to societal expectations adopted by agroholdings' outside investors. In contrast, Gagalyuk (2017) and Gagalyuk et al. (2018) demonstrate that agroholdings in Ukraine not only report about but also engage in a wide variety of CSR activities aiming to improve social and technical infrastructures in rural areas. Initially, instigated by listings on international stock markets, the 
CSR disclosure of Ukrainian agroholdings goes far beyond the mere publication of sustainability chapters in annual corporate reports and involves the communication of CSR activities through corporate websites, local mass media and corporate newspapers. At the same time, Mamonova (2015) found that stakeholders' perceptions of large-scale farms in Ukraine are not necessarily negative. Thus, agroholding engagement in wider (and costlier than otherwise would be required) CSR disclosure either runs counter the instrumental logic or encompasses other implicit or unidentified instrumental motivations.

We argue that the institutional approach to organizational legitimacy is capable of addressing these motivations for CSR disclosure. In their seminal work, Scherer and Palazzo (2007) show that communication becomes the sole source of peaceful interaction and mutual recognition in contexts of rapidly changing or missing societal demands. Therefore, through CSR disclosure, firms in developing and transition economies can proactively engage in the formation of political will and institution building. In contrast to nontransparent lobbying and symbolic responses that may lead to further public accusations (Janning et al., 2020b), deliberate corporate disclosure seeks open dialogue to shape the normative demands of the general public (Scherer and Palazzo, 2007). The institutional-legitimacy perspective thus extends the set of instrumental motivations for CSR disclosure. This view suggests that the CSR disclosure of firms aims not only to avoid monitoring costs and to create a positive image of a firm but also to form a favorable business environment through the recognition and correction of existing socioeconomic imbalances (Aguilera et al., 2007) (Table 1). Although making firm-specific information available to outsiders may seem counter to a firm's direct economic or technical interests, it can improve the sustainability of the firm.

Differences in institutional settings, mediating factors and situational contingencies (e.g. stakeholder influence capacity) may partially explain the distinct findings of transparency research (Carroll and Shabana, 2010). Corporate transparency is, indeed, not generic, so its benefits are not homogeneous. Accordingly, CSR disclosure may play out differently depending on the relative magnitudes of strategic (economic and resource-based) and institution-building motives, which in turn may depend on the strength of institutions, the nature of industry and firms' unique challenges. To scrutinize the importance of different rationales for designing transparent systems in a volatile, nontransparent institutional environment, the present paper explores the example of Ukrainian agroholdings.

\section{Context of Ukrainian agroholdings}

The continuing trend in Ukrainian agriculture toward integrated large-scale operations is both consistent and contradictory. As a country amid economic transition coping with the difficult legacy of its Soviet past, attendant path dependencies and manifold challenges of industrialization, Ukraine has been experiencing a number of institutional weaknesses that encourage nontransparent business practices. Apart from its volatile economic conditions and imperfect factor markets, the country's business environment is often characterized by an entwinement of business and policy and by a nagging mistrust in the free market economy (Sutela, 2012). Not least, increasing stakeholder participation in the public debates on agricultural privileges, practices and responsibilities have revealed manifold conflicting interests, which have made it more difficult for businesses and institutions likewise to resolve related problems (Balmann et al., 2016).

Table 1. Extended instrumental rationale for CSR disclosure.

\begin{tabular}{lll}
\hline Theoretical perspective & Rationale & Complementary strategies and mechanisms \\
\hline Strategic & $\begin{array}{l}\text { Agency cost } \\
\text { minimization; competitive } \\
\text { advantage }\end{array}$ & $\begin{array}{l}\text { Corporate governance; separation of ownership and } \\
\text { control; board diversity; support from salient stakeholders; } \\
\text { corporate reputation; accounting performance; corporate }\end{array}$ \\
& Institution building & $\begin{array}{l}\text { Mocial responsibility disclosure } \\
\text { implementation; public relations leadership }\end{array}$ \\
& &
\end{tabular}


In fact, the intensive political and public debates on agricultural transition in Ukraine and many other post socialist countries led - by accident or design - to imbalanced land reforms in favor of a large-scale agricultural production (Csaki and Lerman, 1997; Sarris et al., 1999). The Ukrainian Land Code of 2001, for example, recognized private land ownership but deferred by moratorium farmland trade by landowners - households and family farms. The investment of agricultural land in the equity capital of newly created businesses was banned to prevent excessive land transfer to corporate farms. The lease terms remained, however, unregulated, which enabled larger agricultural players to extensively accumulate land by means of long-term contracts (OECD, 2012). Tax exemptions and debt restructuring programs that aimed to facilitate farm incomes helped pave the way for further land consolidation by agroholdings and outside investors (Lapa et al., 2015).

These policies additionally bear responsibility for a dramatic deterioration of the socioeconomic situation in rural Ukraine. In Soviet times, agricultural enterprises were engaged in numerous support activities, such as transportation, construction, housing and food processing, along with offering guaranteed employment to the rural population in crop and livestock production. Such enterprises also delivered a wide range of social services, such as kindergarten services, health care facilities and entertainment, and provided financial, in-kind and other support to state-run communal facilities (Keyzer et al., 2013). The abrupt ending of this arrangement during the first stage of economic transition in 1990-1999 weighed heavily on rural communities. Most dramatic was the loss of guaranteed employment, which started a wave of labor migration to cities and undermined morale and motivation in rural areas. Unlike in Soviet times, lease of land plots became the only relation of most rural residents to a farm. At the same time, the newly established corporate farms were released from any duty in the social sphere. The Presidential Decree of March 2000 (Presidential Decree, 2000) entrusted local authorities with the task of providing social, cultural, entertainment and servicing facilities, formerly residing with collective and state farms, while some facilities were privatized. However, a lack of financial resources prevented local authorities from properly accomplishing these tasks (Keyzer $e t$ $a l ., 2013)$. The result was a growing deficit of qualified and loyal farm workers that the majority of corporate farms faced (Koester et al., 2010).

Over the course of land consolidation and corporatization, 1,700 to 1,900 of 13,000 corporate farms became members of agroholdings from 2006-2015 (UCAB, 2016; State Statistics Committee of Ukraine, 2016). The number of agroholdings grew at the same time from zero to 79 (UCAB, 2016). Today, Ukrainian agroholdings farm approximately $17 \%$ of the country's total arable land. The trend toward large-scale farming has been further abetted by the growing global demand for food and integration into world markets, which has made agriculture (and especially crop production) a profitable business (Nivyevskyi et al., 2015). In 2015, agroholdings contributed approximately $20 \%$ of the total crop output, $28 \%$ of the total livestock output and $23 \%$ of the gross agricultural output (UCAB, 2016).

Because of the underlying economies of size and rising orientation toward international food markets, the growth and economic sustainability of large-scale farming hinge on continuing improvements in production and management technologies. To finance these improvements, farms require reliable access to capital. Although economies of size give agroholdings a competitive edge over smaller producers in accessing production factors, domestic factor markets remain imperfect and volatile and lack sufficient support from inherently incomplete or captured institutions. Opting for external capital sources via listings on international stock markets may thus appear economically expedient and less risky. Indeed, 21 Ukrainian agroholdings went public on international stock exchanges with the first initial public offering (IPO) of 2005, raising more than $\$ 1.5$ billion in additional investments (UCAB, 2012). Today, their number has dropped due to mergers and the delisting of some poorly economically performing companies to 10 companies.

An international listing sets higher standards for corporate transparency and disclosure. Despite the positive link that the literature suggests with respect to corporate disclosure and financial performance, the case of Ukrainian agroholdings finds little support for this hypothesis. The correlation matrix presented in Figure 1 shows a very weak interrelationship between the returns on equity of ten listed agroholdings and their 


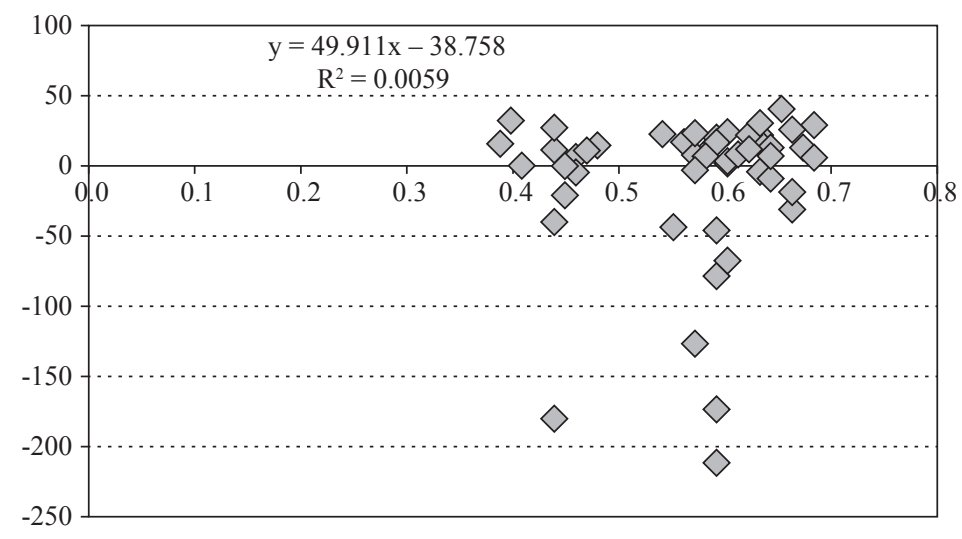

Figure 1. Correlation matrix of returns on equity (\%,y-axis) and the corporate disclosure indexes ( $\%, x$-axis) of ten Ukrainian agroholdings listed on international stock exchanges, 2011-2015.

transparency indices constructed based on the S\&P rating agency's methodology ${ }^{3}$. Although evidence of a stronger relationship may be missing due to performance fluctuations caused by the economic crisis and an ongoing military conflict in the eastern regions of Ukraine, the transparency indicators of agroholdings remain more or less stable. This result implies that the rationales for designing transparent systems among agroholdings may have grounds other than those of immediate economic advantage.

Especially in poor institutional environments, the rationale for more corporate transparency may be different, since existing bottlenecks often make market transactions not only costly but also impossible (Gagalyuk and Valentinov, 2019). Previous research shows that Ukraine is characterized by weak institutions, poor property rights protection and insufficient supervision from government and nongovernmental organizations (NGOs) over corporate compliance (Love and Rachinsky, 2015; Stepanenko, 2006). Furthermore, the laws relating to corporate governance and disclosure frequently contain ambiguous wording or lack specificity, and there are a significant number of inconsistencies between these laws. There is also a widespread perception in the business community that the judiciary is subject to political interference and corruption. All of these factors combine to create an uncertain legal environment in Ukraine (cf. Mycyk et al., 2007: 61). However, the state of given institutional frameworks, e.g. for land use, human capital development and technological adaptation, determines not only the economic but also social benefits of large-scale agricultural investments (Petrick et al., 2013). Particularly in countries with inadequate social security systems, as in Ukraine, firms faced with weak institutions may have more options than simply to adapt to the existing institutional environment. In particular, firms may want to proactively address the existing imbalances, as these may impair their own businesses. The following section provides evidence for how transparency strategies of agroholdings are designed to tackle the problems of imperfect business environments.

\section{Case study results and discussion}

The paper further presents the results of case studies of four Ukrainian agroholdings. The selected agroholdings are large joint stock companies listed on international stock exchanges. The case study analysis is based on data collected during in-depth interviews with corporate managers (Table 2) conducted from SeptemberDecember 2019. The interviewed managers requested that their responses and information about their companies be anonymized. The obtained data were further complemented with information from available

\footnotetext{
${ }^{3}$ According to the S\&P transparency and disclosure methodology (Patel and Dallas, 2002; Patel et al., 2002), companies' annual reports are scrutinized for the disclosure of 98 indicators of transparency capturing ownership structure, financials and corporate governance. Company ratings are assigned based on the ratios of available data points to the maximum number of possible data points. The results of the correlation analysis are not the core of this paper and are presented in support of the argument that financial performance as a common indicator of instrumental rewards for corporate disclosure may not always be the main (intended) outcome of higher transparency.
} 
Table 2. Summary of cases.

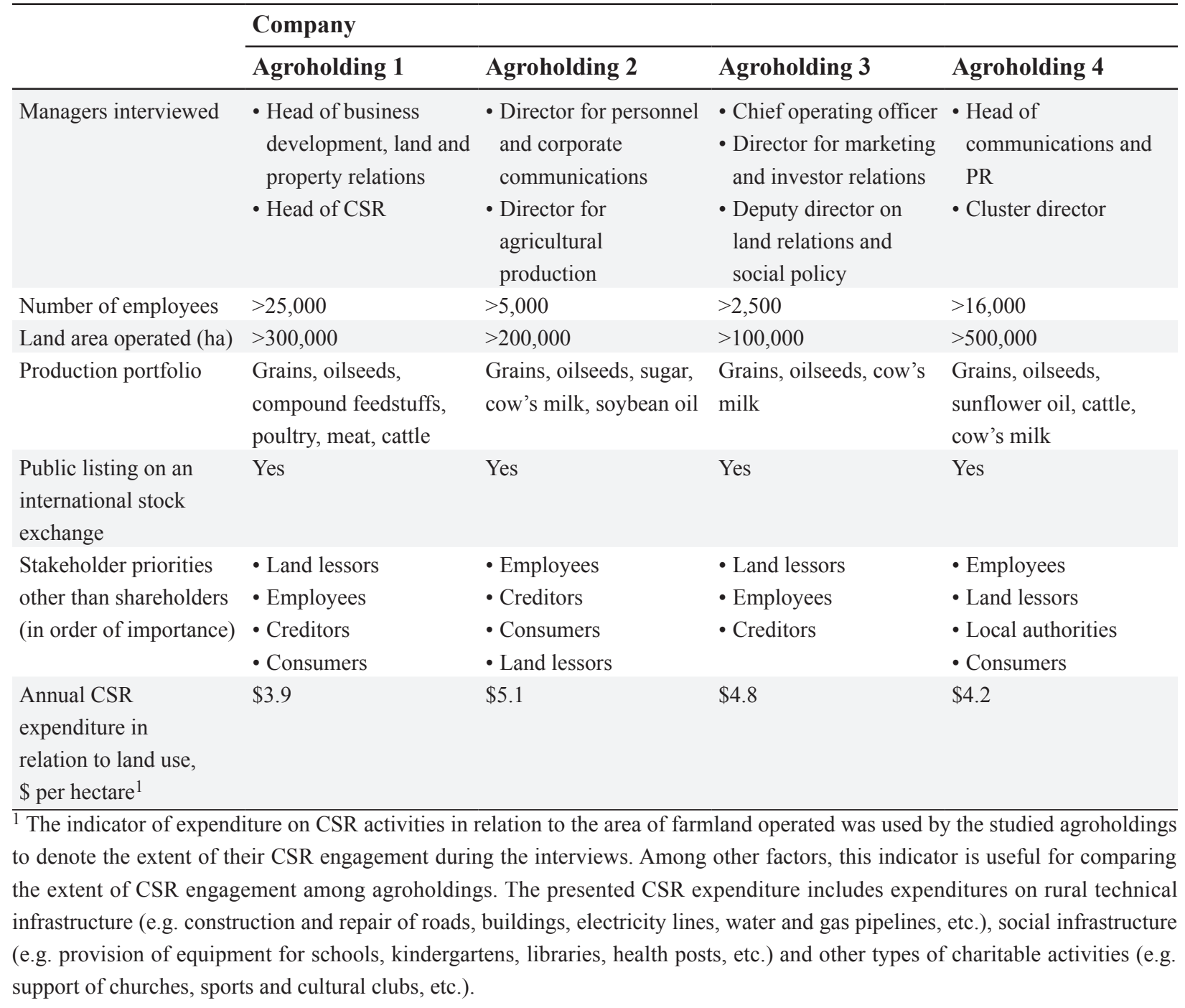

company documents, such as annual financial and nonfinancial (sustainability) reports, presentations for investors and company websites.

The studied companies confirm that Ukrainian legislation does not require businesses to report on CSR or related issues. At the same time, businesses must report on their production and economic and financial indicators.

[...] legislation does not include anything related to corporate social responsibility. No definition of it, no general terms, no procedures, no regulations - nothing. Ukraine is in the early stages of development with regard to corporate social responsibility. Therefore, all of our projects in this area and reporting on these projects are voluntary. Why are we doing this? Well, we have many projects in different spheres, and we prefer to talk about these projects because they have successful, positive results.

(Agroholding 1)

We report everything that is required by legislation, for instance, taxes paid, financials and so on. Regarding other stakeholders of our company, including communities, mass media, shareholders and partners, we regularly meet with them and discuss our plans and results.

(Agroholding 2) 
All of the studied agroholdings point to a combination of strategic- and institutional-legitimacy rationales for their voluntary CSR disclosures, including shareholder-, stakeholder- and institutionalization-related motives. Each of these motivations includes components serving the instrumental needs of agroholdings. We review these motivations for voluntary CSR disclosure below.

\subsection{Strategic-legitimacy motivations for CSR disclosure: the economic perspective}

All of the scrutinized companies are publicly listed on European stock exchanges, in particular, in London and Warsaw. Accordingly, the firms take all of the measures required by these stock exchanges to address agency problems in a comprehensive way. The companies possess corporate units responsible for corporate communications and investor relations and issue regular semiannual and annual corporate reports. The reports disclose information on ownership structures, board of director changes, and financial and operational results. Information, such as that on board membership, corporate governance rules, share prices and shares in free float, is duplicated and regularly updated on corporate websites. Each report publication is announced through a press release. In addition, all studied companies have broad coverage from investment analysts and are audited by well-known audit firms. As pointed out by the interviewed company managers, securing access to capital via a transparent image for outside investors is the main driver of the integrity of corporate reporting.

Our reports are a good instrument for our investors, as they help them understand the business situation and make their suggestions for further business development.

(Agroholding 1)

As a result of listings on European stock markets, the studied agroholdings have to comply with EU legislation. In particular, since 2018, the agroholdings have been required to include a nonfinancial report in their annual reports according to the nonfinancial reporting directive (NFRD) of the EU. The agroholdings argue, however, that they had started issuing nonfinancial reports long before said directive came into effect and that they would have produced such reports even if the NFRD did not exist. Moreover, the scope of nonfinancial reporting by agroholdings is much broader than the NFRD requires and includes the application of many instruments and communication channels in addition to annual reports.

We are obliged to publish a nonfinancial report for all of our stakeholders and investors. [...] Of course, we would do [nonfinancial reporting]. We started issuing this document, if I recall correctly, in 2015 or 2016. We also publish a nonfinancial report based on standard G4 GRI (Global Reporting Initiative) adopted in the European Union. [...] Of course, our communication activities go far beyond official reporting. [...] We publish our corporate newspapers and brochures. (Agroholding 1)

There is a directive in the EU, which requires companies to report about all nonfinancial activities conducted in the past year. We, as a company, have been reporting about these activities since our first year on the stock exchange. [...] We share more information than the EU directive requires. We report based on the GRI standards. Their structure is comprehensive, but anyway, we disclose even more information to provide feedback.

(Agroholding 2)

At the same time, the agroholdings refuse to agree that CSR reporting serves as an entrenchment instrument for them to relieve pressure from investors.

This [using CSR disclosure as a management entrenchment mechanism] is a myth. (Agroholding 2)

Our experience of communication with investors shows that the information on CSR in the annual report is not important for them. Therefore, if disclosure of this information were not obligatory, we would not include it in the annual report. [...] Our experience of communication with investors [...] demonstrates that their own interests $[\ldots]$ are their first priority.

(Agroholding 3) 
We have a chapter in our annual report, which is maybe half a page long, where we report some formal things about sustainable development. Our targeted investment bankers do not want to read everything. They want to know general facts about what we are doing. However, in the villages [of our company's operations], we disclose everything down to the last detail for the local inhabitants.

(Agroholding 4)

In part, these findings contradict the results of previous studies (Gagalyuk, 2017; Hawn and Ioannou, 2016; Ioannou and Serafeim, 2015) that emphasize the growing importance of CSR disclosure for firms' shareholder value and equity capital. Rather, from the listed companies' perspective, formalized and detailed CSR disclosure helps build and maintain strong corporate reputations to attract debt capital. Our further findings support this point.

For instance, all of the studied agroholdings are on loans from well-known international financial institutions (IFIs), such as the International Finance Corporation (IFC) and European Bank for Reconstruction and Development (EBRD). Accordingly, the agroholdings have to comply with the requirements of these organizations for sustainability reporting.

A few years ago, we recognized that, apart from simple communication with people, we have to report. We have two types of reports - one for the IFC and one for the EBRD - and these reports include all information about the requests, complaints and suggestions we have received from rural inhabitants through various communication channels. We have accordingly extended our communication network to include emails, websites, and direct telephone communication with key local managers and farm directors.

(Agroholding 1)

Communication and disclosure serve reputation building. Certainly, corporate reputations affect shareholders' reputations. This is a valuable addition for them although they primarily assess the financial component, which is of highest priority.

(Agroholding 4)

However, motivations of agroholdings for CSR disclosure in this special case seem to be broader than to simply receive loans from renowned lenders such as the IFC and EBRD. IFIs' requirements for corporate conduct are different and more extensive than those of commercial banks since IFIs are accountable to both governments and donor organizations. Therefore, being approved for funding from IFIs allows agroholdings to favorably borrow from commercial banks. Thus, from the agroholdings' standpoint, engagement in broader CSR reporting is key to attracting debt capital rather than equity capital. One reason for this is that loans are more important than equity in financing working capital for everyday business operations. An additional advantage of debt over equity financing is that it does not threaten ownership or control of an agroholding's founding owner.

Furthermore, we find that agroholdings' CSR reporting to lenders has a so-called disciplining effect on the agroholdings themselves. Higher transparency helps agroholdings better structure and coordinate their CSR activities or interact with shareholders and stakeholders.

Reporting is great because it describes everything that we are doing, including innovative and social projects. [...] I can definitely state that our communication is better than that of most companies on the market due to our experience with the IFC and EBRD. They make regular suggestions for improvements and the introduction of new practices. They provide advice very often. We 'bought' their ideas much earlier than the other companies did. This was a gradual process, there was no breakthrough.

(Agroholding 1)

Effective communication helps develop a CSR strategy for our company. $\quad$ (Agroholding 3)

Communication helps coordinate and systemize our projects and scale them up. (Agroholding 4) 


\subsection{Strategic-legitimacy motivations for CSR disclosure: the resource-based perspective}

Competitive advantage is a further, resource-based rationale for corporate transparency as reported by the studied agroholdings. In line with the traditional conceptualization, which sets forth the development of unique capabilities as a source of competitive advantage, agroholdings are using CSR disclosure as a means of differentiation from competitors on the imperfect farmland market. Given that leasing is the only way to access farmland in Ukraine (Gagalyuk et al., 2018), the disclosure of information about one's own community and infrastructure development activities to landowners is vital to maintain their commitment and, thus, to secure long-term investments of businesses in the leased-in farmland.

We disseminate information about our company primarily among [...] our land lessors. Why? Because people tend to migrate from one land user to another land user and we want to avoid this.

(Agroholding 1)

The results of our survey of landowners conducted in 2016 show that landowners' pecuniary selfinterests should be given first priority. A landowner will choose to lease out his or her land to the company that offers a higher rental payment rather than to that which spends much money on CSR programs. At the same time, landowners appreciate whether companies invest in CSR. If a company is not engaged in visible CSR activities, this will be perceived negatively. However, if another company in a neighboring village pays higher land rental payments, then landowners in our village will require us to increase rental payments irrespective of what we are doing in terms of CSR. (Agroholding 3)

In addition to the traditional idea of competitive advantage, another major intention behind higher transparency is to develop a more positive image in the public spotlight. Publicly listed agroholdings strive to improve public opinion about them by disclosing information that is rarely made public by nonlisted corporate and family farms. Such disclosure touches on taxes, land rents and charitable donations paid. The main addressees of this sort of disclosure include company employees, local authorities and especially land lessors, that is, rural inhabitants.

Inhabitants and administrators of the villages where our farms operate are the main target audience [of CSR communication].

(Agroholding 3)

We actively communicate with [...] our land lessors on the regional level. [...] Local rural inhabitants are the largest target audience. In addition, there are local authorities and our own employees in the regions. These are the most important three stakeholder groups although we also communicate with scientists and experts, among others.

(Agroholding 4)

In line with the strategic perspective on organizational legitimacy, we find that the CSR disclosure of agroholdings aims to resolve stakeholder-management conflicts arising, for the most part, from existing institutional bottlenecks. In particular, this approach concerns the abovementioned imperfections of the markets for farmland, labor and equity: (1) the farmland market is characterized by a moratorium on land sales (Gagalyuk, 2017); (2) outmigration of qualified employees from rural areas and employee fraud are the key issues in the labor market (Gagalyuk et al., 2018; Ledeneva, 2008); and (3) illegal takeovers and asset grabbing are major issues in the equity market (Rettman, 2011; Rojansky, 2014). The achievement of landowner and employee loyalty and organizational resilience are the major objectives of CSR disclosure here.

Our CSR disclosure aims to reach out to villagers on the one hand and our local CSR managers on the other. [...] Employees are also part of our CSR. Our CSR communication involves a dialogue with communities, employees, environment and markets.

(Agroholding 1)

Our status as a public company, with hundreds of investors and minor shareholders from all over the world, protects us from asset grabbing to some extent.

(Agroholding 2) 
Landowners' loyalty is the main outcome of our CSR activities. Improvements of landowners' loyalty helped us renew land rental agreements in 2017-2018. [...] We train our employees in our policies regarding human resources and landowners. Our key specialists explain the specifics of these policies to divisional employees and assess whether they require strengthening or whether there are strong candidates that can be promoted within the agroholding.

(Agroholding 3)

Our reputation contributes to support of minor shareholders' rights and protects us from illegal attacks. $[\ldots]$ People who have not worked with us before want to join our company.

(Agroholding 4)

\subsection{Institutional-legitimacy motivations for CSR disclosure}

The results of our case studies point to three general sets of motivations for CSR disclosure from the institutional legitimacy perspective. The first set involves the institutionalization of CSR communication itself as a response to a nontransparent business environment. The studied agroholdings report that they use various media, establish corporate units and assign budgets for CSR communication. Moreover, these activities have spillover effects in the form of imitating strategies being implemented by competing agroholdings.

We have our own website. [...] We want it to be not only an information platform but also a place where one can read about different projects. [...] Regarding our corporate newspaper, it covers two dimensions according to our business structure. One dimension is poultry production, and the other dimension is crop production. Each is characterized by its own specifics and requirements for CSR and stakeholder approaches. This is a purely socially oriented newspaper that provides information exclusively about our social projects. [...] We have information desks, we have local CSR managers in the villages, we have a schedule for village visits. Our managers visit 2-3 villages a day and discuss various issues with local people.

(Agroholding 1)

We understand that there will be no effective interaction with rural inhabitants if continuous planned communication with them is missing. The budget we allocate to our CSR activities is substantial, and therefore, it is important that this money be invested in projects that result in positive long-term outcomes for the community, business and the country as a whole. [...] We have a strategy that encompasses our main priorities of community development including education, culture, sports and others. We have special councils on the regional level where our managers discuss our CSR plans with local representatives. The decisions are made there and communicated to us in a bottom-up manner. Based on these decisions, we develop our CSR budget.

(Agroholding 2)

We regularly report about our CSR activities in our corporate newspapers, which we issue on a monthly basis in each of the regions of our operations. On our Facebook page, we publish information about our CSR events and activities in real time. The information provided through our corporate and social media platforms is much more detailed than that provided in our annual report. (Agroholding 3)

We have a corporate monthly newspaper where we describe all of our social projects. We have a website that provides information about our charity projects. In every village of our operations, we have an information desk that presents our projects and events. We hold meetings in the villages, in which we present our semiannual social reports. [...] We were the first to introduce such communication instruments, and our competitors copied them afterwards. For example, our information desks were the first of their kind. [...] We assess the number of people we cover through our newspapers and Facebook page. This is our quantitative key performance indicator (KPI), whereas the qualitative KPI refers to perceptions of our information by the target audience. We measure it by surveying our land lessors.

(Agroholding 4) 
Second, CSR disclosure appears to be an integral part of the CSR policies implemented by agroholdings. The approach serves as a stewardship instrument of agroholding management that helps communicate corporate values and raise awareness of problems that persist in the business environment.

According to Ukrainian legislation, we, as a legal entity, are not allowed to own farmland while it is important to our land lessors how much they are paid for their land. Therefore, we are intentional that our CSR is not an instrument of land accumulation. Instead, it embodies our responsible attitude toward land. We implement effective measures, we benefit from them, and we save money. [...] Our CSR is an instrument for the realization of our values.

(Agroholding 2)

Our CSR engagement is rather problem driven. The state often fails to address infrastructural issues in rural areas, including the development of schools, kindergartens, rural health posts, electricity lines, water supply, roads and so on. Community budgets are generally unable to solve these problems. However, our employees and their families live in these areas and, therefore, we have to invest in rural infrastructure.

(Agroholding 3)

CSR is our worldview, while highly efficient production is our self-fulfillment goal.

(Agroholding 4)

The third set of institutional-legitimacy motivations for CSR disclosure resonates with the second set: agroholdings perceive CSR communication as a proactive feedback mechanism. However, in contrast to the top-down stewardship rationale, the main motive here is to establish mutual exchange and create a culture of an open dialogue among relevant stakeholders. This approach is particularly in line with the views of Scherer and Palazzo (2007) on the role of communication in the sphere of public will formation. Moreover, in the context of Ukraine, where paternalistic expectations and a low level of general cooperativeness persist among farm stakeholders (Gagalyuk et al., 2013; Koester, 2005), the open dialogue approach serves as an essential step forward in the promotion of private initiative and the formation of civil society.

We consider it [CSR communication] a mechanism of feedback and control. (Agroholding 2)

In what ways do transparency and communication help us? They are helpful in establishing dialog with people. For example, this year (2019), we had a very nice project where we organized a roundtable with local family farmers and together developed a snow removal map with the distribution of tasks between us and the farmers. There was a case when local farmers approached us, and we cosponsored the construction of a boiler for a kindergarten. Such transparent action brings our company to a new level. We are open to communicate and cooperate even with our competitors because we all understand that we belong together and we can solve problems together.

(Agroholding 1)

We have projects aiming to fund creative people, regardless of their age. Any person willing to launch a small business in the region of our operations can approach us and receive funding. There are a few preconditions for receiving funding though. First, the business should be located in the same region. Second, it should be profitable. Third, there should be a social component. For example, it is not enough for a businessman to just produce raspberries. In addition, he should commit himself to supplying a certain volume of raspberries to a local kindergarten.

(Agroholding 1)

Overall, the obtained results suggest that the CSR disclosure of agroholdings pursues two general objectives. On the one hand, it aims to facilitate agroholdings' adaptation to existing stakeholder pressures and institutional bottlenecks, such as transparency requirements of international stock markets and imperfections of local factor markets. Here, the agroholdings are either not willing or have little power to change the status quo. For instance, to obtain access to additional capital, they must comply with the transparency requirements of lending institutions. At the same time, the agroholdings' actual main stakeholders are landowners. Given that farmland sales are prohibited, investments in the leased-in farmland are insecure. There is a threat that 
a significant number of landowners may get better rental offers from competing agroholdings and withdraw from existing rental contracts. Therefore, from the strategic perspective, landowners' loyalty is the main aim of the CSR disclosure of agroholdings.

On the other hand, the CSR disclosure of agroholdings serves as an integral part of their broader efforts to transform the institutional environment by inducing changes in this environment. The agroholdings' excessive and voluntary CSR disclosure in the environment characterized by rather low demand for transparency can be considered CSR itself, as it goes beyond what is prescribed by law or existing norms. In fact, our respondents frequently referred to CSR disclosure itself as a socially responsible activity. We find that both the strategicand institutional-legitimacy CSR disclosures are driven by the instrumental motivations of agroholdings. The two perspectives differ, however, by their intent. The aim of strategic legitimation is to create and appropriate value from the agroholdings' interactions with stakeholders, while the institutional legitimation activities pursue the establishment of a favorable environment for value creation and appropriation.

This dichotomy of motivations for CSR disclosure resonates with the classical distinction between institutional arrangements and the institutional environment proposed by new institutional economists (North, 1990). The former refers to mutual (and most often bilateral) commitments established by contracts between agents (cf. Brousseau and Raynaud, 2011: 66; Williamson, 1985). As such, the notion of institutional arrangements generally corresponds to strategic-legitimacy motivations for CSR disclosure explored in the present study. The institutional environment includes the general institutions of societies that set the 'rules of the game' and make them mandatory (cf. Brousseau and Raynaud, 2011: 65). Thus, the transformation or establishment of the institutional environment involves institution building (or institutionalization), which corresponds to the institutional-legitimacy rationale for the CSR disclosure of agroholdings. Local institutional arrangements are less complex and time consuming than generic institution building. However, such arrangements may serve as a starting point for the design of broader institutional systems (ibid). Our results demonstrate that a large portion of agroholdings' CSR disclosure efforts relate to institutional arrangements with their stakeholders. Nevertheless, our findings also show that these efforts give rise to a progressive adoption of new local rules that may be encapsulated within the broader norms of a transparent business environment. To this effect, two of the four agroholdings studied here are members of the Ukrainian Center for Development of Corporate Social Responsibility, whose objective is to promote a country-wide adoption of CSR policies and to raise awareness of sustainable development goals.

However, the extent to which institutionalization and the encapsulation of local institutional arrangements will occur, as well as the governance mode agroholdings should select to make them happen, depends largely on the weakness of existing institutions. In particular, it is important to understand whether incomplete or captured institutions are an obstacle to encapsulation (Dorobantu et al., 2017). Institutions are incomplete when the rules governing value creation and appropriation are either absent or insufficiently enforced; in turn, institutions are captured when robust rules and structures exist but have been captured by a narrow set of elite interests (ibid.: 125). Our findings suggest that CSR disclosure as an independent (i.e. individual) legitimation strategy of agroholdings may play out well in addressing incomplete institutions, but it may be ineffective or more time and effort consuming in the case of captured institutions:

We have faced negative attitudes from local opinion leaders since we started informing the rural population about our activities. This is clear because people used to live in an information vacuum that facilitated the proliferation of myths such as water or air pollution allegedly being caused by our operations. As soon as we started disclosing more information about our activities and these opinion leaders recognized that their myths were no longer supported, their reactions became even more negative. However, we try to maintain a dialogue with them. Our main achievement is that rural inhabitants are no longer afraid to express their opinions. They can visit us, call us via a special hotline or drop a letter into our special mailbox to express their complaints. We then meet with them and do our best to reach consensus.

(Agroholding 1) 
It is often the case that we create something good for a village, for example, we might improve street lighting, and then come back in half a year and be told that the village head is such a good guy because he introduced street lighting. Wait, what? We did it! We have to inform and reach out to local people to make them understand who is doing all of these good things for them. [...] We do not want to be an 'unrecognized hero.' Therefore, we first do something, then we tell the mass media about it and then we understand that we have to do even more.

(Agroholding 4)

The CSR strategies of agroholdings, including their approaches to CSR disclosure, are generally adaptable and may change once their institutional environment changes. If legislation lifts the moratorium on land sales, agroholdings will obtain the possibility to buy land and thereby to reduce the amount of leased-in land. It is, however, doubtful that agroholdings will be able to own land on the scale they currently operate based on lease, at least in the mid-term perspective. Given that huge size of agroholdings' operations is largely driven by their willingness to exercise economies of scale, they will expectedly continue leasing-in vast farmland areas and engaging in the CSR activities that target their numerous land lessors. It is also possible that agroholdings reconfigure their strategies further to benefit from changes in the land policy frameworks. To make lease-based land use less uncertain, they may form pools of loyal landowners and, for example, lend money to them to buy farmland from less loyal landowners to subsequently lease it out to agroholdings. Should such strategies be pursued, we expect the institution-building motivations for CSR to be gradually driven out by the strategic legitimacy concerns followed by respective institutional arrangements.

\section{Conclusions}

The traditional instrumental argument for corporate transparency fails to sufficiently appreciate the proactive and seemingly unrewarded CSR disclosure initiatives of firms operating in weak institutional environments. This paper contends that for countries in transition to a market economy, instrumental motivations take on a much broader meaning than a mere justification of immediate tangible benefits over costs. The present case study analysis of CSR disclosure in a transitional business environment examines this contention for four publicly listed Ukrainian agroholdings.

The analysis shows that the scope and magnitude of the problems that these firms face arise from bottlenecks in the institutional environment that often make market transactions not only costly but also impossible. Illegal takeovers, shareholder rights violations and uncertain access to land, finance and qualified labor are the repercussions of insecure property rights, weak contract enforcement, corruption and nepotism. These circumstances impel firms to opt for voluntary engagement in actions that go beyond legal prescriptions, in particular with regard to corporate disclosure. More importantly, these actions bear the potential to have positive spillover effects in the form of the institutionalization of transparent business practices and, in the context of a weak institutional environment, represent instrumental endeavors of firms. In this way, firms not only adapt to fluctuations in the business environment associated with information asymmetries and competition but also change the business environment through institution building. The likelihood of these processes spurring the design of robust institutional systems depends largely on the weaknesses, i.e. incompleteness, or capture of existing institutions.

As this paper demonstrates, the institutional-legitimacy perspective of the firm is helpful for the theoretical incorporation of this development into the instrumental logic of corporate transparency. In particular, the perspective delivers arguments capable of explaining recent findings of blurred boundaries between mutually nonexclusive instrumental and moral motivations for socially responsible corporate action and communication (Gagalyuk, 2017; Grouiez, 2014; Miranda and Grandori, 2020; Visser et al., 2019). Furthermore, the paper empirically verifies the theoretical proposition that firms' moral considerations may take the form of instrumental motivations for deliberate socially responsible actions in weak institutional environments (Balmann et al., 2016). Meeting stronger international requirements for transparency and disclosure along with voluntary engagements in nonmarket initiatives triggers adjustments in domestic institutions that benefit firms in both the short and long run. 


\section{Acknowledgment}

The authors would like to express their gratitude to the Leibniz Association and the project 'International Competence Center on Large Scale Agriculture (LaScalA)' for their support in conducting this research. The publication of this article was funded by the Open Access Fund of the Leibniz Association

\section{References}

Aguilera, R.V., D.E. Rupp, C.A. Williams and J. Ganapathi. 2007. Putting the S back in corporate social responsibility: a multilevel theory of social change in organizations. The Academy of Management Review 32(3): 836-863.

Ashforth, B.E. and B.W. Gibbs. 1990. The double-edge of organizational legitimation. Organization Science 1: $177-194$.

Balmann, A., L. Chatalova, T. Gagalyuk and V. Valentinov. 2016. Gesellschaftliche Verantwortung in der landwirtschaftlichen Tretmühle: Moderne Landwirtschaft, technologische Tretmühle und gesellschaftliche Entfremdung - Folgen, Herausforderungen und Lösungsansätze. In: Moderne Landwirtschaft zwischen Anspruch und Wirklichkeit - Eine kritische Analyse. DLG Verlag, Berlin, Germany, pp. 147-170.

Bansal, P. and K. Roth. 2000. Why companies go green: a model of ecological responsiveness. The Academy of Management Journal 43(4): 717-736.

Beiting, C., I. Ioannou and G. Serafeim. 2014. Corporate social responsibility and access to finance. Strategic Management Journal 35: 1-23.

Bennis, W., D. Goleman and J. O'Toole. 2008. Transparency: how leaders create a culture of candor. JosseyBass, San Francisco, CA, USA.

Brousseau, E. and E. Raynaud. 2011. 'Climbing the hierarchical ladders of rules': a life-cycle theory of institutional evolution. Journal of Economic Behavior \& Organization 79: 65-79.

Bujaki, M. and B.J. McConomy. 2002. Corporate governance: factors influencing voluntary disclosure by publicly traded Canadian firms. Canadian Accounting Perspectives 1(2): 105-139.

Carroll, A.B. and K.M. Shabana. 2010. The business case for corporate social responsibility: a review of concepts, research and practice. International Journal of Management Reviews 12(1): 85-105.

Csaki, C. and Z. Lerman. 1997. Land reform and farm restructuring in East Central Europe and CIS in the 1990s: expectations and achievements in the first five years. European Review of Agricultural Economics 24: 428-452.

Davis, J.H., F.D. Schoorman and L. Donaldson. 1997. Toward a stewardship theory of management. The Academy of Management Review 22: 20-47.

De Klerk, M., C. De Villiers and C. Van Staden. 2015. The influence of corporate social responsibility disclosure on share prices: evidence from the United Kingdom. Pacific Accounting Review 27(2): 208-228.

Dhaliwal, D., O. Li, A. Tsang and Y. Yang. 2011. Voluntary non-financial disclosure and the cost of equity capital: the case of corporate social responsibility reporting. Accounting Review 86(1): 59-100.

Dhaliwal, D., O. Li, A. Tsang and Y. Yang. 2014. Corporate social responsibility disclosure and the cost of equity capital: the roles of stakeholder orientation and financial transparency. Journal of Accounting and Public Policy 33(4): 328-355.

Dorobantu, S., A. Kaul and B. Zelner. 2017. Non-market strategy research through the lens of new institutional economics: an integrative review and future directions. Strategic Management Journal 38: 114-140.

Durnev, A., V. Errunza and A. Molchanov. 2009. Property rights protection, corporate transparency, and growth. Journal of International Business Studies 40: 1533-1562.

Elsbach, K.D. 1994. Managing organizational legitimacy in the California cattle industry: the construction and effectiveness of verbal accounts. Administrative Science Quarterly 39: 57-88. 
European Union (EU). 2014. Directive 2014/95/EU of the European Parliament and of the Council of 22 October 2014 amending Directive 2013/34/EU as regards disclosure of non-financial and diversity information by certain large undertakings and groups. Official Journal of the European Union L 330: 1-9. http://data.europa.eu/eli/dir/2014/95/oj

Fung, B. 2014. The demand and need for transparency and disclosure in corporate governance. Universal Journal of Management 2(2): 72-80.

Gagalyuk, T. 2017. Strategic role of corporate transparency: the case of Ukrainian agroholdings. International Food and Agribusiness Management Review 20(2): 257-277.

Gagalyuk, T. and V. Valentinov. 2019. Agroholdings, turbulence, and resilience: the case of Ukraine. Journal of East European Management Studies 24(3): 484-496.

Gagalyuk, T., J.H. Hanf and M. Hingley. 2013. Firm and whole chain success: network management in the Ukrainian food industry. Journal on Chain and Network Science 13(1): 47-70.

Gagalyuk, T., V. Valentinov and F. Schaft. 2018. The corporate social responsibility of Ukrainian agroholdings: the stakeholder approach revisited. Systemic Practice and Action Research 31(6): 675-698.

Galuchi, T.P.D., F.P. Rosales and M.O. Batalha. 2019. Management of socioenvironmental factors of reputational risk in the beef supply chain in the Brazilian Amazon region. International Food and Agribusiness Management Review 22(2): 155-171.

Gider, D. and U. Hamm. 2019. How do consumers search for and process corporate social responsibility information on food companies' websites? International Food and Agribusiness Management Review 22(2): 229-246.

Grouiez, P. 2014. Farming strategies regarding 'social responsibility' in the Russian agricultural sector. East-West Journal of Economics and Business 12(1): 63-84.

Hawn, O. and I. Ioannou. 2016. Mind the gap: the interplay between internal and external actions in the case of corporate social responsibility. Strategic Management Journal 36: 2569-2588.

Hellberg-Bahr, A. and A. Spiller. 2012. How to treat farmers fairly? Results of a farmer survey. International Food and Agribusiness Management Review 15: 87-98.

Hermans, F., F.R. Chaddad, T. Gagalyuk, S. Senesi and A. Balmann. 2017. The emergence and proliferation of agroholdings and mega farms in a global context. International Food and Agribusiness Management Review 20(2): 175-185.

Hoogiemstra, R. 2000. Corporate communication and impression management - new perspectives why companies engage in corporate social reporting. Journal of Business Ethics 27: 55-68.

Ioannou, I. and G. Serafeim. 2015. The impact of corporate social responsibility on investment recommendations: analysts' perceptions and shifting institutional logics. Strategic Management Journal 36: 1053-1081.

Jahansoozi, J. 2006. Organization-stakeholder relationships: exploring trust and transparency. Journal of Management Development 25: 942-955.

Janning, F., W. Khlif and C. Ingley. 2020a. Transparency is (full) disclosure in corporate governance. In: F. Janning, W. Khlif and C. Ingley (eds.) The illusion of transparency in corporate governance. does transparency help or hinder true ethical conduct? Palgrave McMillan, Cham, Switzerland, pp. 57-82.

Janning, F., W. Khlif and C. Ingley. 2020b. Transparency a paradoxical proxy for trust? In: F. Janning, W. Khlif and C. Ingley (eds.) The illusion of transparency in corporate governance. does transparency help or hinder true ethical conduct? Palgrave McMillan, Cham, Switzerland, pp. 83-107.

Jauernig, J. and V. Valentinov 2019. CSR as hypocrisy avoidance: a conceptual framework. Sustainability Accounting, Management and Policy Journal 10(1): 2-25.

Keyzer, M.A., M.D. Merbis, R. Witt, V. Heyets, O. Borodina and I. Prokopa. 2013. Farming and rural development in Ukraine: making dualisation work. European Commission Joint Research Centre, Institute for Prospective Technological Studies, Seville, Spain.

Kinderman, D. 2019. The challenges of upward regulatory harmonization: the case of sustainability reporting in the European Union. Regulation \& Governance 14: 674-697.

Koester, U. 2005. A revival of large farms in Eastern Europe - how important are institutions? Agricultural Economics 32(1): 103-113.

Koester, U., C. Schumann and A. Lissitsa. 2010. The agricultural knowledge and information system in Ukraine - call for reforms. German-Ukrainian Agricultural Policy Dialogue, Kyiv, Ukraine. 
Langbein, J. 2015. Transnationalization and regulatory change in the EU's eastern neighbourhood: Ukraine between Brussels and Moscow. Routledge, London, UK.

Lapa, V., T. Gagalyuk and I. Ostapchuk. 2015. The emergence of agroholdings and patterns of land use in Ukraine. In: A. Schmitz and W.H. Meyers (eds.) Transition of agricultural market economies - the future of Kazakhstan, Russia and Ukraine. CABI, Wallingford, UK, pp. 102-110.

Ledeneva, A. 2008. Blat and Guanxi: informal practices in Russia and China. Comparative Studies in Society and History 50(1): 118-144.

Lev, B., C. Petrovits and S. Radhakrishnan. 2010. Is doing good good for you? Yes, charitable contributions enhance revenue growth. Strategic Management Journal 31(2): 182-200.

$\mathrm{Li}, \mathrm{X} .2010$. The impacts of product market competition on the quantity and quality of voluntary disclosures. Review of Accounting Studies 15(3): 663-711.

Love, I. and A. Rachinsky. 2015. Corporate governance and bank performance in emerging markets: evidence from Russia and Ukraine. Emerging Markets Finance and Trade 51: 101-121.

Luhmann, H. and L. Theuvsen. 2016. Corporate social responsibility in agribusiness: literature review and future research directions. Journal of Agricultural and Environmental Ethics 29: 673-696.

Luyt, I., N. Santos and A. Carita. 2013. Emerging investment trends in primary agriculture: a review of equity funds and other foreign-led investments in the CEE and CIS region. Food and Agriculture Organization of the United Nations, Rome, Italy.

Mamonova, N. 2015. Resistance or adaptation? Ukrainian peasants' responses to large-scale land acquisitions. Journal of Peasant Studies 42: 607-634.

McWilliams, A. and B. Siegel. 2001. Corporate social responsibility: a theory of the firm perspective. The Academy of Management Review 26(1): 117-127.

Miranda, B.V. and A. Grandori. 2020. Structural heterogeneity in farm structures: a configurational approach. Journal of Agribusiness in Developing and Emerging Economies 10(1): 65-83.

Mycyk, A., E. Cook and D. Fedoruk. 2007. Corporate governance and disclosure in Ukraine. International Journal of Disclosure and Governance 4(1): 59-74.

Nivyevskyi, O., O. Stepaniuk, V. Movchan, M. Ryzhenkov and Y. Ogarenko. 2015. AGRICISTRADE country report: Ukraine. Institute of Economic Research and Policy Consulting, Kiev, Ukraine. Available at: http://tinyurl.com/jpvhar6

North, D.C. 1990. Institutions, institutional change and economic performance. Cambridge University Press, Cambridge, UK.

Oliver, C. 1991. Strategic responses to institutional processes. The Academy of Management Review 16(1): 145-179.

Organisation for Economic Cooperation and Development (OECD). 2004. OECD principles of corporate governance. OECD, Paris, France.

Organisation for Economic Cooperation and Development (OECD). 2012. Competitiveness and private sector development: Ukraine 2011 sector competitiveness strategy. OECD, Paris, France.

Palazzo, G. and A.G. Scherer. 2006. Corporate legitimacy as deliberation: a communicative framework. Journal of Business Ethics 66: 71-88.

Patel, S.A. and G. Dallas. 2002. Transparency and disclosure: overview of methodology and study results - United States. Standard \& Poor's, New York, NY, USA.

Patel, S.A., A. Balic and L. Bwakira. 2002. Measuring transparency and disclosure at firm level in emerging markets. Emerging Markets Review 3: 325-337.

Perotti, E. and E. Von Thadden. 2005. Dominant investors and strategic transparency. Đournal of Law, Economics, \& Organization 21: 76-102.

Petrick, M., J. Wandel and K. Karsten. 2013. Rediscovering the Virgin Lands: agricultural investment and rural livelihoods in a Eurasian frontier area. World Development 41: 164-179.

Pfeffer, J. and G. Salancik. 1978. The external control of organizations: a resource dependence perspective. Harper \& Row, New York, NY, USA.

Pirson, M. and D. Malhotra. 2011. Foundations of organizational trust: what matters to different stakeholders? Organization Science 22: 1087-1104. 
Plotnick, J. 2010. Corporate reputation and transparency: the good, the bad, and the ugly. Journal of Public Relations and Advertising 3(1): 16-33.

Presidential Decree, 2000. Decree of the President of Ukraine No. 398/2000 on some measures for improving economic activity conditions of non-state agricultural enterprises, March 9, 2000. Government of Ukraine, Kyiv, Ukraine.

Raithel, S. and M. Schwaiger. 2015. The effects of corporate reputation perceptions of the general public on shareholder value. Strategic Management Journal 36: 945-956.

Rawlins, B. 2009. Give the emperor a mirror: toward developing a stakeholder measurement of organizational transparency. Đournal of Public Relations Research 21(1): 71-99.

Rettman, A. 2011. EU companies at risk of 'raiders' in Ukraine. EUobserver, 16 December 2011. Available at: https://euobserver.com/foreign/114646

Rindova, V., I. Williamson and A. Petkova. 2010. When is reputation an asset? Reflections on theory and methods in two studies of business schools. Journal of Management 3: 610-619.

Roberts, P.W. and G.R. Dowling. 2002. Corporate reputation and sustained superior financial performance. Strategic Management Journal 23: 1077-1094.

Rojansky, M. 2014. Corporate raiding in Ukraine: causes, methods and consequences. Demokratizatsyia: Journal of Post-Soviet Democracy 22(3): 411-443.

Rupley, K.H., D. Brown and S. Marshall. 2017. Evolution of corporate reporting: from stand-alone corporate social responsibility reporting to integrated reporting. Research in Accounting Regulation 29(2): 172-176.

Sarris, A.H., T. Doucha and E. Mathijs. 1999. Agricultural restructuring in central and eastern Europe: implications for competitiveness and rural development. European Review of Agricultural Economics 26(3): 305-329.

Scherer, A.G. and G. Palazzo. 2007. Toward a political conception of corporate responsibility: business and society seen from a Habermasian perspective. The Academy of Management Review 32(4): 1096-1120.

Schnackenberg, A. and E. Tomlinson. 2016. Organizational transparency: a new perspective on managing trust in organization-stakeholder relationships. Journal of Management 42(7): 1784-1810.

Serpa, R. 1985. Creating a candid corporate culture. Journal of Business Ethics 4: 425-430.

Shell, G.R. 2004. Make the rules or your rivals will. Crown Business, New York, NY, USA.

State Statistics Service of Ukraine. 2016. Agriculture of Ukraine. Statistical Yearbook. State Statistics Service of Ukraine, Kyiv, Ukraine.

Stepanenko, V. 2006. Civil society in post-Soviet Ukraine: civic ethos in the framework of corrupted sociality? East European Politics and Societies 20(4): 571-597.

Suchman, M.C. 1995. Managing legitimacy: strategic and institutional approaches. Academy of Management Review 20(3): 571-610.

Sutela, P. 2012. The underachiever: Ukraine's economy since 1991. Carnegie Endowment, Washington, DC, USA.

Thorne, L., L.S. Mahoney and G. Manetti. 2014. Motivations for issuing standalone CSR reports: a survey of Canadian firms. Accounting, Auditing \& Accountability Journal 27(4): 686-714.

Ukrainian Agribusiness Club (UCAB). 2012. Entry to international financial markets: guidelines for agribusiness. UCAB, Kyiv, Ukraine.

Ukrainian Agribusiness Club (UCAB). 2016. Agroholdings of Ukraine 2016. UCAB, Kyiv, Ukraine.

Verrecchia, R.E. 2001. Essays on disclosure. Journal of Accounting and Economics 32: 97-180.

Visser, O., A. Kurakin and A. Nikulin. 2019. Corporate social responsibility, coexistence and contestation: large farms' changing responsibilities vis-à-vis rural households in Russia. Canadian Journal of Development Studies 40(4): 580-599.

Visser, O., N. Mamonova and M. Spoor. 2012. Oligarchs, megafarms and land reserves: understanding land grabbing in Russia. Journal of Peasant Studies 39(3-4): 899-931.

Vogel, D.J. 2005. Is there a market for virtue? The business case for corporate social responsibility.|California Management Review 47: 19-45. 
Widmar, N.O., C.A. Wolf, C.J. Morgan, W.S. Downey and C.C. Croney. 2019. Who's responsible here? US resident perceptions of food retailer social responsibility. International Food and Agribusiness Management Review 22(3): 339-350.

Williamson, O.E. 1985. The economic institutions of capitalism: firms, markets, relational contracting. Free Press, New York, NY, USA.

Yang, X. and C. Rivers. 2009. Antecedents of CSR practices in MNCs' subsidiaries: a stakeholder and institutional perspective. Journal of Business Ethics 86: 155-169.

Zink, K.J. 2005. Stakeholder orientation and corporate social responsibility as a precondition for sustainability. Total Quality Management and Business Excellence 16: 1041-1052. 
